\title{
Usage of ICT Tools for Diffusion of Agricultural Information
}

\author{
Vikas $^{1}$, K. K. Shashidhara ${ }^{2 *}$, B. S. $\operatorname{Reddy}^{3}$ and S. B. Goudappa ${ }^{2}$ \\ ${ }^{1}$ Department of Agricultural Extension Education, UAS, Raichur, 584104, India \\ ${ }^{2}$ Department of Agricultural Extension Education, College of Agriculture, Bheemaryangudi, \\ UAS, Raichur, 585 287, India \\ ${ }^{3}$ Department of Agricultural Economics, Agricultural Extension Education Centre, \\ Bheemaryangudi, UAS, Raichur, 585 287, India \\ *Corresponding author
}

\begin{tabular}{l} 
K e y w o r d s \\
ICT, Usage, \\
$\begin{array}{l}\text { Diffusion, } \\
\text { Extension person }\end{array}$ \\
\hline Article Info \\
\hline $\begin{array}{l}\text { Accepted: } \\
\text { 22 June 2020 } \\
\text { Available Online: } \\
\text { 10 July 2020 }\end{array}$ \\
\hline
\end{tabular}

\section{A B S T R A C T}

The study was conducted in North Eastern Karnataka and Raitha Samparka Kendra's (RSKs) of Kalaburgi and Raichur districts were selected for the study. The result of the study revealed that cent per cent of the extension personnel were using television for the purpose of obtaining knowledge/current agricultural events followed by internet $(96.25 \%)$ and mobile phone $(91.25 \%)$. Similarly an equal per cent $(77.50 \%)$ of extension personnel using computer and mobile phone, tabs $(75.00 \%)$ for the purpose of transfer of technology, followed by television (68.75\%). Majority of the Extension personnel were always using television $(63.75 \%)$ for diffusion of agricultural information. More than fifty five per cent of the extension personnel were adopted pendrive from past 0-2 years. Nearly half (47.50 $\%$ ) of the respondents were adopted Mobile phone from past 4-6 years for diffusion of agricultural information.

\section{Introduction}

The information and communication support during last fifty years has mainly been conventional method. Earlier the extension personnel used to disseminate the technology/ message to farmers orally/manually. In practical sense communication is the essence of extension services. Extension services, both people and approaches, seek to provide rural people with knowledge and information. Traditionally, extension used to transfer the knowledge from researchers or external experts to farmers through training, demonstrations and field visits. These programmes rely on face-to-face teaching and learning, tend to be propagated slowly and are small in scale and limited in coverage. Hence, 
limited extension service could not able to reach the majority of the farmers scattered over larger geographical area. This gap remains a challenge for extension system even today. The extension system has yet to exploit the full potential of the ICT tools and other communication techniques (Hage Manty, 2011).

The advancement in ICT can be utilized for providing accurate, timely, relevant information and services to the farmers, thereby facilitating an environment for more remunerative agriculture. However, all the ICT initiatives are not uniform with disparities between regions in the level and quality of telecommunications, information and the effort of individuals, public and private organizations and differentiated nature of demand of the farmers in different areas.

Diffusion can be defined as the process by which an innovation is communicated through certain channels over the time among members of a social system (Rogers, 1995). The generation, diffusion and application of agricultural knowledge is increasingly important, especially for small and marginal farmers, who need relevant information in order to improve, sustain and diversify their farm enterprises. Agriculture can require substantial knowledge transfer to farmer and among farmers, including information about successful farming practices, new technologies or controls of pest and disease outbreaks, and new markets. ICTs offer opportunities to reach more people and to carry out various functions within extension systems more effectively and efficiently. ICTs will provide easy access to local or global information knowledge and they are simple channels for two-way communication (Sudath, 2008). With this back ground the study was carried to examine the extent of usage of ICTs by extension personnel for diffusion of agricultural information among the extension personnel.

\section{Materials and Methods}

The study was conducted in North Eastern Karnataka of Kalaburgi and Raichur districts i.e. Aland, Afzalpur, Gulbarga, Chincholi, Chittapur, Sedam and Jewargi, Raichur, Deodurga, Lingasugur, Sindhanur and Manvi were considered and all the RSK's were selected for the study. The research design adopted for the study was 'Ex post-facto' since the phenomenon has already happened and the design was considered appropriate. Extension personnel working in the department of Agriculture i.e., Agricultural Officer (AO) and Assistant Agricultural Officer (AAO) were considered as sample for the study. Respondents were selected by obtaining list from ADA Office of the selected taluks of Kalaburgi and Raichur districts. Random sampling procedure was followed to select 80 extension personnel from Kalaburgi and Raichur districts. Diffusion was operationalized as the process by which the Agricultural information is communicated over period of time among the extension personnel of Department of Agriculture.

The ICT tools selected for the study were television, radio, pendrive, handycam, digital camera, printer, video player (CD/DVD player), projector (video conferencing), CD ROM, GPS (global positioning system), computer, mobile phone, tab and ICT services selected are internet, e-mail, e-magazines, ebulletins, mobile based apps (whatsapp, hike, telegram and facebook) voice and text messages and search engines (google, bing and yahoo). Totally 13 ICT tools and 7 ICT services were selected for the study. It was measured by using teacher developed test, it consists of 13 ICT tools and 7 ICT services were considered for the study. The Extension personnel were asked to indicate the diffusion of agricultural information through ICT tools and services by Always, Sometimes and Never, with scoring pattern of 3,2 and 1 
respectively. The score against all the ICT tools were added to get the individual respondents maximum score of 39 and 13 as minimum score. Score for each pattern was followed for ICT services with maximum score of 21 and minimum score of 7 . The data collected from the respondents were scored, tabulated and analyzed using frequency, percentage, mean and standard deviation.

\section{Results and Discussion}

It is evident from Table 1 that, cent per cent of the extension personnel were using television for the purpose of obtaining knowledge/ current agricultural events, followed by computer $(96.25 \%)$, mobile phone $(91.25 \%)$. All these tools are very useful means of getting information, for e.g. television provides picture with synchronized sound which made easier for people to learn, whereas, computer and mobile phone as easy way to get information at their finger tips and these are owned by everyone now-a-days. Through computer and mobile connected to internet one can easily search information and gain knowledge. This finding is in line with the findings of Hage Manty (2011).

Results showed that an equal per cent (77.50 $\%$ ) of Extension personnel using computer and mobile phone, Tabs $(75.00 \%)$ for the purpose of transfer of technology, followed by television $(68.75 \%)$. The reason might be television can refresh and entertain people after a hectic work so serve as a tool in broadcasting the new innovations and transfer of technology. Computer, mobile and tab are most common means of communication now a days. It is highly utilized for keeping in touch with family, friends, colleagues, other organizations and thus helps in transfer of technology.

The utilization of ICT tools for teaching/ training indicated that majority of extension personnel used pen drive $(87.50 \%)$ and projector $(75.00 \%)$. Reason might be highly qualified extension personnel, facilities made available by the department for use and skills required in operating the tools. Extension personnel used projectors for teaching to make it attractive and pen drive to store information and presentation, video conferencing is used for teaching online it might be through projectors. Further, it is indicated that, 87.50 per cent of extension personnel used mobile phone for the purpose of organizational communication followed by printer $(50.00 \%)$ and video conferencing $(47.50 \%)$.

The results presented in the Table 2 indicated that, cent per cent of respondents used google to obtain knowledge. A large majority of the extension personnel were using internet $(95.00 \%)$ for the purpose of obtaining knowledge/current events, followed by whatsapp (82.50\%), e-mail $(67.50 \%)$, hike $(62.50 \%)$, face book $(61.25 \%)$, voice and text messages $(50.00 \%)$. Reason might the regular usage mobile phone and mobile based services like internet, whatsapp, hike, face book and e-mail as easy way to get information at their finger tips. This finding is in line with the findings of Hage Manty (2011). Regarding use of ICT tools for transfer of technology revealed that 66.25 per cent of the extension personnel using whatsapp for transfer of technology, internet (56.25\%), facebook and voice and text messages $(53.75 \%)$. An equal per cent of the respondents $(45.00 \%)$ were using e-mails and search engines. Reason might the regular usage and connectivity of farmers and extension personnel among themselves through mobile phone and mobile based services like internet, whatsapp, faebook and e-mail.

More than half $(53.75 \%)$ of the Extension personnel were using google as search engine for the purpose of teaching/ training, followed 
by voice and text messages (35.00\%), internet $(25.00 \%)$, whatsapp $(20.00 \%)$, email $(10.00 \%)$, e-magazines $(8.75 \%)$ and facebook $(3.75 \%)$. With respect to use of ICT tools for the purpose of organizational communication, cent per cent of them using whatsapp followed by 58.75 per cent of them used voice and text messages and e-mail by 46.25 per cent. The reason behind this might be Extension personnel formed groups at hoblli, taluk and district level through mobile based services like whatsapp and facebook for communication between them. Further, cent per cent of the extension personnel used internet for diagnosing the field problems with reference videos/ clippings, followed by voice and text messages $(87.50 \%)$, google $(82.00 \%)$, whatsapp $(81.25 \%)$ and hike $(62.50 \%)$.

The results on diffusion pattern of agricultural information through ICT tools presented in the Table 3 indicated that majority of the extension personnel were always using television $(63.75 \%)$ for diffusion of agricultural information, followed by mobile phone $(58.75 \%)$, computers $(50.00 \%)$. The probable reason for this could be that all the mentioned ICT tools are quit common now a day's and are the needs of every man in today's world. Mobile phone are utilized for keeping in touch with each other, mobile are prefer more due its value added service such as mobile-internet, video call, whatsapp, blue tooth etc. Similarly majority $(65.00 \%)$ of the extension personal were sometimes using tab for diffusion of agricultural information.

A per cent of them used printer, pendrive and video conferencing. The probable reason for this could be that tab is used in dissemination of agricultural information, so this might be reason to result this kind of result. However, cent per cent of extension personal were never used video/voice recorder, followed by $\mathrm{CD}$ ROM (85.00\%) and GPS (68.75\%). Reason might be the mobile comes with many services which include video/voice recording, video playing and video editing etc., which resulted in replacement of this kind of tools, and in case of CDROM it has been replaced with CD and DVDs.

Adoption of ICT tools for diffusion of agricultural information was shown in the Table 4. The results indicated that cent per cent of the extension personnel were adopted tab and pendrive (56.25\%) from past 0-2 years for diffusion of agricultural information. It is evident that, 46.25 per cent of the extension personnel were adopted computer from past 2-4 years for diffusion of agricultural information. Reason might be because computer are very common now-adays, most of the people can afford it easily, Computer is used for sending and making reports, many other office related work can be carried out in short period of time and with less amount of labour so with this kind of features it became popular among people and Extension personnel and used it in diffusion of agricultural information.

Nearly half $(47.50 \%)$ of the respondents were adopted Mobile phone from past 4-6 years diffusion of agricultural information. Majority $(81.25 \%)$ of the Extension personnel were adopted CD-ROM from past 6-8 years diffusion of agricultural information. Reason behind this could be the popularity of CDROM in the past 6-8 years for its size and storage of information for future purpose. In the present era these are replaced with pendrive and DVD.

Reason might be because mobile phone are very common now-a-days, most of the people can afford it easily, regular use of voice call to contact and for transferring any video/voice message, usage of mobile based services which in turn helps extension personnel contacts and communicate with each other easily. 
Table.1 Purpose of utilization of ICT tools by the extension personnel

$\mathrm{n}=80$

\begin{tabular}{|c|c|c|c|c|c|c|c|c|c|}
\hline \multirow{4}{*}{ Sl. No } & \multirow{4}{*}{ ICT tool } & \multirow{2}{*}{\multicolumn{8}{|c|}{ Purpose of utilization }} \\
\hline & & & & & & & & & \\
\hline & & \multicolumn{2}{|c|}{$\begin{array}{l}\text { For obtaining } \\
\text { knowledge/current } \\
\text { agricultural events }\end{array}$} & \multicolumn{2}{|c|}{$\begin{array}{l}\text { For transfer of } \\
\text { technology }\end{array}$} & \multicolumn{2}{|c|}{$\begin{array}{l}\text { For teaching or } \\
\text { training }\end{array}$} & \multicolumn{2}{|c|}{$\begin{array}{l}\text { For organizational } \\
\text { communication }\end{array}$} \\
\hline & & Freq & $\%$ & Freq & $\%$ & Freq & $\%$ & Freq & $\%$ \\
\hline 1 & Television & 80 & 100 & 55 & 68.75 & 0 & 0 & 0 & 0 \\
\hline 2 & Radio & 12 & 15.00 & 40 & 50.00 & 0 & 0 & 0 & 0 \\
\hline 3 & Handycam & 12 & 15.00 & 40 & 50.00 & 3 & 3.75 & 0 & 0 \\
\hline 4 & Digital camera & 43 & 53.75 & 43 & 53.75 & 16 & 20.00 & 0 & 0 \\
\hline 5 & Printer & 59 & 73.75 & 39 & 48.75 & 10 & 12.50 & 40 & 50.00 \\
\hline 6 & $\begin{array}{l}\text { Video player ( CD/DVD } \\
\text { player) }\end{array}$ & 48 & 60.00 & 43 & 53.75 & 03 & 3.75 & 0 & 0 \\
\hline 7 & Projector & 32 & 40.00 & 28 & 35.00 & 60 & 75.00 & 18 & 22.50 \\
\hline $\mathrm{i}$ & Video conferencing & 13 & 16.25 & 43 & 53.75 & 33 & 41.25 & 38 & 47.50 \\
\hline 8 & CD-ROM & 07 & 8.75 & 06 & 7.50 & 0 & 0 & 0 & 0 \\
\hline 9 & $\begin{array}{l}\text { GPS (Global positioning } \\
\text { system) }\end{array}$ & 43 & 53.75 & 09 & 11.25 & 03 & 3.75 & 04 & 5.00 \\
\hline 10 & Computer & 77 & 96.25 & 62 & 77.50 & 62 & 77.50 & 26 & 32.50 \\
\hline 11 & Mobile phone & 73 & 91.25 & 62 & 77.50 & 40 & 50.00 & 70 & 87.50 \\
\hline 12 & Pendrive & 0 & 0 & 0 & 0 & 70 & 87.50 & 0 & 0 \\
\hline 13 & $\mathrm{Tab}$ & 0 & 0 & 60 & 75.00 & 0 & 0 & 0 & 0 \\
\hline
\end{tabular}


Table.2 Purpose of utilization of ICT services for serving the farming community by Extension personnel

$\mathrm{n}=80$

\begin{tabular}{|c|c|c|c|c|c|c|c|c|c|c|c|}
\hline \multirow[t]{2}{*}{$\begin{array}{l}\text { Sl. } \\
\text { No. }\end{array}$} & \multirow[t]{2}{*}{ ICT services } & \multicolumn{2}{|c|}{$\begin{array}{c}\text { For obtaining } \\
\text { knowledge/current } \\
\text { agricultural events }\end{array}$} & \multicolumn{2}{|c|}{$\begin{array}{l}\text { For transfer of } \\
\text { technology }\end{array}$} & \multicolumn{2}{|c|}{$\begin{array}{c}\text { For teaching or } \\
\text { training }\end{array}$} & \multicolumn{2}{|c|}{$\begin{array}{l}\text { For organizational } \\
\text { communication }\end{array}$} & \multicolumn{2}{|c|}{$\begin{array}{l}\text { For diagnosing the field } \\
\text { problems with reference } \\
\text { videos/clippings }\end{array}$} \\
\hline & & Freq & $\%$ & Freq & $\%$ & Freq & $\%$ & Freq & $\%$ & Freq & $\%$ \\
\hline 1 & Internet & 76 & 95.00 & 45 & 56.25 & 20 & 25.00 & 14 & 17.50 & 80 & 100 \\
\hline 2 & e-mail & 54 & 67.50 & 36 & 45.00 & 08 & 10.00 & 37 & 46.25 & 0 & 0 \\
\hline 3 & e-magazines & 15 & 18.75 & 9 & 11.25 & 07 & 8.75 & 11 & 13.75 & 0 & 0 \\
\hline 4 & e-bulletins & 8 & 10.00 & 6 & 7.50 & 0 & 0 & 10 & 12.50 & 0 & 0 \\
\hline 5 & Mobile based apps & & & & & & & & & & \\
\hline a. & Whatsapp & 66 & 82.50 & 53 & 66.25 & 16 & 20.00 & 80 & 100 & 65 & 81.25 \\
\hline b. & Hike & 50 & 62.50 & 30 & 37.50 & 03 & 3.75 & 25 & 31.25 & 50 & 62.50 \\
\hline c. & Telegram & 20 & 25.00 & 0 & 0 & 0 & 0 & 03 & 3.75 & 0 & 0 \\
\hline d. & Facebook & 49 & 61.25 & 43 & 53.75 & 03 & 3.75 & 04 & 5.00 & 25 & 31.25 \\
\hline 6. & $\begin{array}{l}\text { Voice and text } \\
\text { messages }\end{array}$ & 40 & 50.00 & 43 & 53.75 & 28 & 35.00 & 47 & 58.75 & 70 & 87.50 \\
\hline 7. & Search engines & & & & & & & & & & \\
\hline a. & Google.com & 80 & 100 & 36 & 45.00 & 43 & 53.75 & 25 & 31.25 & 66 & 82.00 \\
\hline b. & Bing.com & 28 & 35.00 & 20 & 25.00 & 0 & 0 & 03 & 3.75 & 10 & 12.50 \\
\hline c. & Yahoo.com & 31 & 38.75 & 28 & 35.00 & 03 & 3.75 & 15 & 18.75 & 10 & 12.50 \\
\hline
\end{tabular}


Table.3 Diffusion pattern of Agricultural Information through ICT tools $n=80$

\begin{tabular}{|c|c|c|c|c|c|c|c|}
\hline \multirow[t]{2}{*}{ Sl.no. } & \multirow[t]{2}{*}{ ICT tool } & \multicolumn{2}{|c|}{ Always } & \multicolumn{2}{|c|}{ Sometimes } & \multicolumn{2}{|c|}{ Never } \\
\hline & & $\begin{array}{l}\text { Fre } \\
q\end{array}$ & $\%$ & $\begin{array}{l}\text { Fre } \\
\text { q }\end{array}$ & $\%$ & $\begin{array}{l}\text { Fre } \\
\mathbf{q}\end{array}$ & $\%$ \\
\hline 1 & Television & 51 & 63.75 & 29 & 36.25 & 0 & 0 \\
\hline 2 & Radio & 10 & 12.50 & 32 & 40.00 & 38 & 47.50 \\
\hline 3 & Handycam & 0 & 0 & 0 & 0 & 80 & 100 \\
\hline 4 & Digital camera & 0 & 0 & 35 & 43.75 & 45 & 56.25 \\
\hline 5 & Printer & 37 & 46.25 & 40 & 50.00 & 03 & 3.75 \\
\hline 6 & Video player ( CD/DVD player) & 30 & 37.50 & 11 & 13.75 & 39 & 48.75 \\
\hline 7 & Projector & 33 & 41.25 & 35 & 43.75 & 12 & 15.00 \\
\hline $\mathrm{i}$ & Video conferencing & 17 & 21.25 & 37 & 46.25 & 26 & 32.50 \\
\hline 8 & CD-ROM & 0 & 0 & 12 & 15.00 & 68 & 85.00 \\
\hline 9 & GPS (Global positioning system) & 0 & 0 & 25 & 31.25 & 55 & 68.75 \\
\hline 10 & Computer & 40 & 50.00 & 37 & 46.25 & 03 & 3.75 \\
\hline 11 & Mobile phone & 47 & 58.75 & 33 & 41.25 & 0 & 0 \\
\hline & i. Internet & 41 & 51.25 & 26 & 32.50 & 13 & 16.25 \\
\hline & ii. e-mail & 32 & 40.00 & 38 & 47.50 & 10 & 12.50 \\
\hline & iii. Whatsapp & 55 & 68.75 & 25 & 31.25 & 0 & 0 \\
\hline 12 & Pendrive & 35 & 43.75 & 40 & 50.00 & 05 & 6.25 \\
\hline 13 & $\mathrm{Tab}$ & 28 & 35.00 & 52 & 65.00 & 0 & 0 \\
\hline
\end{tabular}


Table.4 Usage of ICT tools over a period of time for diffusion of agricultural information by Extension personnel $n=80$

\begin{tabular}{|c|c|c|c|c|c|c|c|c|c|c|c|}
\hline \multirow{2}{*}{$\begin{array}{l}\text { Sl. } \\
\text { No }\end{array}$} & \multirow[t]{2}{*}{ ICT tool } & \multicolumn{2}{|c|}{ 0-2 years } & \multicolumn{2}{|c|}{ 2-4 years } & \multicolumn{2}{|c|}{ 4-6 years } & \multicolumn{2}{|c|}{ 6-8 years } & \multicolumn{2}{|c|}{ 8-10 years } \\
\hline & & Freq & $\%$ & Freq & $\%$ & Freq & $\%$ & Freq & $\%$ & Freq & $\%$ \\
\hline 1 & Television & 07 & 8.75 & 20 & 25.00 & 30 & 37.50 & 03 & 3.75 & 20 & 25.00 \\
\hline 2 & Radio & 03 & 3.75 & 20 & 25.00 & 21 & 26.25 & 09 & 11.25 & 27 & 33.75 \\
\hline 3 & Handycam & 0 & 0 & 10 & 12.50 & 7 & 8.75 & 31 & 38.75 & 32 & 40.00 \\
\hline 4 & Digital camera & 15 & 18.75 & 30 & 37.50 & 15 & 18.75 & 20 & 25.00 & 0 & 0 \\
\hline 5 & Printer & 15 & 18.75 & 30 & 37.50 & 10 & 12.50 & 22 & 27.50 & 3 & 3.75 \\
\hline 6 & $\begin{array}{l}\text { Video player (CD/DVD } \\
\text { player) }\end{array}$ & 05 & 6.25 & 12 & 15.00 & 20 & 25.00 & 39 & 48.75 & 04 & 5.00 \\
\hline 7 & Projector & 13 & 16.25 & 25 & 31.25 & 20 & 25.00 & 12 & 15.00 & 10 & 12.50 \\
\hline $\mathrm{i}$ & $\begin{array}{l}\text { Video } \\
\text { conferencing }\end{array}$ & 17 & 21.25 & 22 & 27.50 & 30 & 37.50 & 08 & 10.00 & 03 & 3.75 \\
\hline 8 & CD-ROM & 0 & 0 & 0 & 0 & 12 & 15.00 & 65 & 81.25 & 03 & 3.75 \\
\hline 9 & $\begin{array}{l}\text { GPS (Global positioning } \\
\text { system) }\end{array}$ & 28 & 35.00 & 30 & 37.50 & 17 & 21.25 & 05 & 6.25 & 0 & 0 \\
\hline 10 & Computer & 30 & 37.50 & 37 & 46.25 & 11 & 13.75 & 02 & 2.50 & 0 & 0 \\
\hline 11 & Mobile phone & 10 & 12.50 & 17 & 21.25 & 38 & 47.50 & 12 & 15.00 & 03 & 3.75 \\
\hline 12 & Pendrive & 45 & 56.25 & 35 & 43.75 & 0 & 0 & 0 & 0 & 0 & 0 \\
\hline 13 & $\mathrm{Tab}$ & 80 & 100 & 0 & 0 & 0 & 0 & 0 & 0 & 0 & 0 \\
\hline
\end{tabular}


Further, 40.00 per cent were used handycam from past 8-10 years for diffusion of agricultural information. The reason might be that, handycam served as a tool for recording actions of any demonstrations, conference and visits etc. so that it can be rewind and used for diffusion of information when ever needed. In the present era the handycam have been replaced with new ICT tools like mobile phones.

In conclusion, majority of the respondents do not have proper infrastructure facilities and ICT tools and services, even though ICT is very much important for effective transfer of technology. Hence, Department of Agriculture should give due importance for providing infrastructure facilities and purchase of new ICTs for the effective use. There should provision for more number of recruitment of technical staff and they must possess proven skills in utilization of ICT facilities which will be helpful in diffusion of Agricultural information. There is a need for extension personnel to update their knowledge and skill on information and communication technology (ICTs). This will increase their information utilization and dissemination of Agricultural information.

\section{References}

Aboh, C. L., 2008, Assessment of the frequency of ICT tools usage by agricultural extension agents in IMO state, Nigeria, Journal of Agricultural Society and Research (JASR)., 8(2):4548.

Ajayi, A. O., Alabi, O. S. and Akinsola, T. O., 2013, Knowledge and perception of extension agents on information and communication technologies (ICTs) use in extension service delivery in Ondo State in Nigeria. African journal of agricultural research., 8(48): 62266233.
Balappa S. R. and Hugar, L. B., 2003, An economic evaluation of onion production and its marketing system in Karnataka. Agricultural Marketing 46(2): 22-26.

B.S.Reddy, 1997, Production, Marketing and Processing of Redgram in Gulbarga district-An Economic Analysis. M.Sc.(Agri) Thesis University of Agricultural Sciences, Dharwad.

Dixit, A. K., Singh, M.K., Roy, A.K., Reddy, B. S. and Narendra Singh, 2015, Trends and contribution of grazing resources to livestock in different states of India. Range Management and Agroforestry. 36 (2): 204-210.

Goudappa S.B., Reddy B. S. and Chandrashekhar, S.M., 2012, Farmers perception and awareness of crop insurance in Karnataka. Indian Research Journal of Extension Education. 12 (Spl.iss.Vol-II):218-222.

Hugar, L. B., Balappa Shivaraya and Yeriswamy, J., 2001, Dynamics of consumer behaviour in vegetable marketing. Indian Journal of Marketing, 31(9-10):27-33.

Joyous, S. T., and Paul, E. M., 2016, Study on social factors that influence use of ICT in agricultural extension in Southern Africa. Agriculture, 6: 15.

Hage Manty., 2011, Access and use of ICT tools by extension personnel for transfer of technology in North Karnataka. M.Sc. (Agri.) Thesis, University of Agricultural Sciences, Dharwad.

Rogers, E., 1995, The Diffusion of Innovations, Fourth Edition. Free Press, New York.

Salau, E. S. and Saingbe, N. D., 2008, Access and utilization and communication technologies (ICT) among agricultural researchers and extension workers. 4(2): 1-11.

Samansiri, B, A, D. and Wanigasundera, W, A, D, P., 2014, Use of information and 
communication technology (ICT) of the tea small holdings development authority of Sri Lanka. Tropical Agricultural Research, 25(4): 460 -475.

Shankaraiah., 2011, Attitude of farmers and scientists towards technology dissemination through mobile message service, MSc (Agri) Thesis. University of Agricultural Sciences.Bangalore, Karnataka (INDIA).

Shashidhara K.K. and Krishna S. Maraddi, 2016, A study on extent of ICT facilities used by rural youths in Yadgir district of Karnataka, International Journal of Agricultural Sciences. 8(56):3064-3066.

Sudath, A., 2008, The role of information technology in diffusion of innovations to the farm level in Australian agribusiness system. Ph.D. Thesis, Victoria University.

Sulaiman, U., Michael, W. M., Olayemi, Y. T. and Rabiu, S., 2015, Awareness and use of information and communication technologies among extension agents in Kaduna State of Nigeria. Journal of Agricultural Extension, 19(1): 66-76.

\section{How to cite this article:}

Vikas, K. K. Shashidhara, B. S. Reddy and Goudappa, S. B. 2020. Usage of ICT Tools for Diffusion of Agricultural Information. Int.J.Curr.Microbiol.App.Sci. 9(07): 3712-3721. doi: https://doi.org/10.20546/ijcmas.2020.907.435 